\title{
THE EXEGESIS OF WOMAN LEADERSHIP ACCORDING TO 1 CORINTHIANS 11:2-16
}

\author{
Dr. Dr. Hannas, Th.M, M,Th, ${ }^{1}$ Rinawaty, Th.M, Ph.D (in progress) ${ }^{2}$ \\ ${ }^{1}$ Vice President for Academic Affairs of Harvest International Theological Seminary Jakarta \\ E-mail: hannas@hits.ac.id \\ ${ }^{2}$ Lecturer of Harvest International Theological Seminary Jakarta \\ E-mail: rinawaty@hits.ac.id
}

\begin{abstract}
The role of woman until now still encounters various problems, such as in the leadership. Do women have decent capacity to lead, or they are on second class under men. This research, brings up to the readers the original understanding about the role of woman especially in leadership. To see woman leadership, the researchers using exegesis method by utilizing four Bible analysis, these are: contextual analysis, syntactical analysis, verbal analysis, theological analysis, and homiletical analysis.

Study which was done toward this research found out that woman essential leadership is how the man and woman aware that leadership which is designed by God, the Creator, is leadership based on function, where the man and the woman realize their roles and function corresponding with God's created nature. Man are leader, who lead with obedience and love. Whereas woman are under man's authority who has to be followed with respect and full of love.
\end{abstract}

Keywords : women, leadership, function, Paul, Corinthians. 


\section{Introduction}

Women exploitation has long story in this planet. That's why evenly in every society anywhere in the world there is always a figure rises up fighting for equality of rights for these people who are considered weak. "French Revolution (1789)" which led the changes for Europe and surroundings, carried on this petition too. Since that time the women's life in Europe never be the sama again. In Indonesia there was R. A. Kartini with her fortune nobility had opportunity to savor European education (Dutch). After being proficient in Dutch, in her bedroom, she liked to interact through letters with her friends at that land of the windmill. She stated the apprehension towards the fate of the women in her country where they couldn't get the freedom and egual rights. Women in her time had low social status. While she told about that, Kartini herself had entered her pinned time and she had quitted from school since she was 12-year old.

The predecessors as R. A. Kartini maybe never imagined there will be Megawati Soekarnoputri who set foot on President of Republic Of Indonesia Palace as the only one Vice President and the fifth President. All the time the authority always be held by men. Megawati shew that woman could also actively take a role and participate in political world. She was able to smash general response of the society to date that women cann't do the work like the men. ${ }^{1}$ The world will never forget Margaret Thatcher, Great Britain Former Prime Minister with the longest tenure along the $20^{\text {th }}$ century (1979 - 1990), and she was the only woman who took that office. A Soviet journalist dubbed her "Iron Lady." Senator Nancy Pelosi from California State is a head of opposition party in United States of America parliament. Before that, she served as chairman of the parliament, first American woman who held that position. Julia Gillard was a first woman who became Australia Prime Minister. Queen Elizabeth II has occupied the throne of United Kingdom for the last 60 years. $^{2}$ These women has shown their capability if they are given the opportunity and credence, they can be good country leaders.

${ }^{1} 100$ Wanita Paling Berpengaruh di Indonesia - 31 Januari 2010, http://jenstea.wordpress.com/2010/01/31/10wanita-paling-berpengaruh-di-indonesia. Accessed: 28-10$201822: 14$

${ }^{2} 100$ Wanita Paling Berpengaruh Sejagat - Jum'at, 4 Januari 2013, http://life.viva.co.id/news/read/379416100wanita-paling-berpengaruh-sejagat. Accessed: 28-10-2018 $22: 17$
Again a good news came from survey results in business world, where Grant Thornton International released an annual report Women in Business 2018 related with gender variety in business world, on Thursday, August 3, 2018. In its review this global audit services company shows there is strong correlation between gender variety in the leadership with a company success. In other word, in relation with women, their survey results in 35 countries with almost 5000 repondents show that women who are in senior role in business have contribution in developing the company performance. ${ }^{3}$

Facts and phenomenon of women success either in country leadership or business these days are claimed as sweet fruit from the equality and freedom indictment for women which is echoed since centuries ago. Now, this movement isn't only personal struggles in isolated local cultural context, but this movement has been a global movement and surges almost all fields of life. Patrilineal institutions considered as obsolete and cruel, unintentionally Church and family units get the same accusation. The rising up of $20^{\text {th }}$ century feminist theologians, demands the redefinition about the women's role from the homes until on the church pulpits.

Apostles Paul in his letter to Corinthians admonished women in that local church because of their performance in service meeting considered humiliating their husband and the community of believers. In 1 Corinthians 11:2-16, Paul laid his teaching about ordonnance of men and women dan described their roles in relation with reflecting God's glory.

\section{A. The Comprehension of Women Leadership}

In Kamus Besar Bahasa Indonesia (Indonesia Dictionary), the term "Leadership" is a form of noun which means the way to lead. ${ }^{4}$ American Dictionary of English Language, defines leadership as : (1) One that leads or conducts; a guide; a conductor, (2) A chief; a commander; a captain, (3) One who goes first. ${ }^{5}$ Webster's New World, defines leadership as one that leads; guiding head. ${ }^{6}$ Oxford Advanced

\footnotetext{
${ }^{3}$ http://lifestyle.bisnis.com/read/20180308/220/747784/ survei-women-in-business-kinerja-perusahaan-naik-jikaperempuan-lebih-banyak Accessed: 2-10-2018 18:39

${ }^{4}$ Tim Prima Pena, "Kepemimpinan" dalam Kamus

Besar Bahasa Indonesia (Jakarta: Gitamedia Press, t. t.), 612.

${ }^{5} \mathrm{http}: / /$ webstersdictionary1828.com/Dictionary/leader Accessed: 29-10-2018 21:12

"Webster's New World, "Leadership" Webster's New World Compact Desk Dictionary And Style Guide (USA: Macmillan, 2002), 245.
} 
Learner's Dictionary of Current English defines leadership as being a leader; power of leading; the qualities of a leader. ${ }^{7}$

John C. Maxwell, an expert in leadership in his book Mengembangkan Kepemimpinan Di Dalam Diri Anda (Developing The Leader Within You) explains tha leadership is influence (the ability to get the followers). ${ }^{8}$ According to him, leadership is an ability inside a man that makes his surrounds following him or do he wishes.

In line with Maxwell in the matter that leadership is influencing, Robert W.Terry adds the element of changes and interaction in the group. According to Terry, leadership is an interaction between the members of a group where the leaders are the agents of changes which actions influence others rather than others' action influence them. ${ }^{9}$ What are concluded by experts in this younger generation aren't much different with the previous generation, represented by Weschler and Massarik (1961), who viewed leadership as interpersonal influence, carried out in certain situations, and directed through communication process, to reach certain on more goals. ${ }^{10}$ Typically previous generation who was longer patient, the experts emphasized the needs of a process to influence other. In that process, goals must be communicated clearly so that people can be moved to reach them.

Leadership related with woman that woman leadership is a woman who has very strong influence more than her surroundings, including the men. With that influence, a woman guiding, encouraging, persuading her surroundings to do an action based on a goal that has been set. In her freedom, a woman can control and manage a group of people as her wishes. This is what is called woman leadership.

\section{B. Biblical Foundation about Woman Leadership According To 1 Corinthians 11:2-16 \\ 1 Corinthians 11:2-16 will be viewed} excegetically, differents with eisegesis. Henry A. Virkler explains :

${ }^{7}$ Oxford Advanced Learner's, "Leadership" Oxford Advanced Learner's Dictionary of Current English (Oxford: Oxford University Press, 1974), 480.

${ }^{8}$ John C. Maxwell, Developing The Leader Within You: Mengembangkan Kepemimpinan Di Dalam Diri Anda (Jakarta: Binarupa Aksara, 1995), 2.

$9{ }^{9}$ Robert W. Terry, Kepemimpinan Autentik (Batam Center: Interaksara: 2002), 37.

${ }^{10} \mathrm{http} / / / \mathrm{www}$.gurupendidikan.com/21-definisi-

kepemimpinan-menurut-para-ahli/ Accessed: 28-09-2018 19:02
Exegesis is the application of the principles of hermeneutics to arrive at a correct understanding of the text. The prefix ex ("out of," or "from") refers to the idea that the interpreter is attempting to derive his understanding from the text, rather than his meaning into the text (eisegesis). ${ }^{11}$

Eisegesis is opposite exegesis because excegesis is the application of the principles of hermeunetic which is done to find the right understanding of a text. Exegesis which are done by the researchers are: contextual analysis, syntactical analysis, verbal analysis, theological analysis, and homiletical analysis.

\section{Contextual Analysis of The Letter of 1 Corinthians}

Corinth was an ancient city of Greece which was rebuilt as Rome colony at $46 \mathrm{AD} .{ }^{12}$ Located in a narrow isthmus which connectiong the mainland of Greece with Peloponesos Island. ${ }^{13}$ With its position as an important harbor in one of the most crowded route at Mediterranean. ${ }^{14}$ Corinth became prosperous trading center with plural society (society diversity). This Greece Metropolitan city was an intellectually arrogant city, materially wealth, and morally corrupt. All kinds of sins broke out violently in this city that was famous because of obscene acts and lusts. ${ }^{15}$ Paul visited Corinth in his second mission journey about 18 months (Acts 18:11,18). At Corinth, Paul met Aquila and Priscilla who had same occupation with him, tent maker. At first, Paul ministry at Jewish synagogue didn't get good response. But, when he preached in a house of a new believer, Titius Justus (Acts 18:7), the Corinthians started repenting and believed. From that time, the church of Corinth grew in big quantity and had influence in that city. With different backgrounds

Church of Corinth was a heterogen church, because the congregation consisted of Jewish, Greece, and people from various places which were colonies

${ }^{11}$ Henry A. Virkler, Hermeneutics: Priciples and Process of Biblical Interpretation. Twelfth printing (Grand Rapids, Michigan: Baker Book House, 1993), 18.

${ }^{12}$ John Drane, Memahami Perjanjian Baru (Jakarta: BPK Gunung Mulia, 1996), 335.

${ }^{13} \mathrm{~S}$. Lewis Johnson, The Wycliffe Bible Commentary: Tafsiran Alkitab Wycliffe, peny. Charles F. Pfeiffer, pent. Gandum Mas (Malang: Gandum Mas, 2007), 3:775.

${ }^{14}$ Drane, Memahami Perjanjian Baru, 350.

${ }^{15}$ Donald C. Stamps, "1 Korintus," dalam Full Life Study Bible: Alkitab Penuntun Hidup Berkelimpahan, pen. Nugroho Hananiel, peny. Bertha Gaspersz, cet. Pertama (Malang: Gandum Mas, 1994), 1887. 
of Romans Empire. ${ }^{16}$ With various backgrounds (culture, education, and beliefs), Corinth congregation faces a lot of problems in understanding and applying Christian teaching. There were many unsolved problems by Paul's right-hand men in Corinth. Therefore, it was necessary to denounce the condition of Corinth's congregation to Paul who was currently at Ephesus. The letter from Corinth was set with hope to get the answer and solution of all practical problems which appeared in the church. This letter is a response letter from Paul to Church of Corinth, to solve every single existing problem in the church he built and loved. The accuracy of Corinth letter's writing, Stamps stated it was written around 55/56 $\mathrm{AD},{ }^{17}$ that was in Paul's third mission journey. Besides straightening out many problems that arised, also this letter contains many Paul's answers about doctrine and church behavior in church service. The following is the approaching of one of the problems in Church of Corinth which will be researched by the writers.

According to the tradition, while praying, the Jewish, either men or women, wearing a cover (comp. 2 Cor. 3:14). As well to the Romans. ${ }^{18}$ While, the Greek, without the same fear to the Lord, prayed without any cover. ${ }^{19}$ According to social habits that applied at that time, a courteous woman only appeared in public with covered head. ${ }^{20}$ According to T.W. Davies in his book Dictionary of the Bible, "There is no lady in a village in the East goes out without cover, and if she does it, she is in a danger of being misunderstood" 21 In Eastern world, "a cover is a mark of inferiority, but a cover is also a mark of big protection."22 Your Honour William Ramsay stated, "In Eastern world, a cover is a strength, an honor, and a dignity of a woman." ${ }^{23}$ In Eastern world a cover is not only a mark of low position of a woman, but also a protection which

\footnotetext{
${ }^{16}$ Billy Kristanto, Ajarlah Kami Bertumbuh (Surabaya: Momentum, 2011), ix.

${ }^{17}$ Stamps, "1 Korintus," dalam Full Life Study Bible: Alkitab Penuntun Hidup Berkelimpahan, 1877.

${ }^{18}$ Norman Hillyer, Tafsiran Alkitab Masa Kini, pent. Harun Hadiwijono (Jakarta: Yayasan Komunikasi Bina Kasih/OMF, 1986), 3:501.

${ }^{19}$ Ibid., 3:501.

${ }^{20}$ John Drane, Memahami Perjanjian Baru (Jakarta: BPK Gunung Mulia, 1996), 358

${ }^{21}$ William Barclay, Pemahaman Alkitab Setiap Hari: Surat $1 \& 2$ Korintus (Jakarta: Gunung Mulia, 2008), 177.

${ }^{22}$ Ibid., 177.
${ }^{23}$ Ibid., 177
}

must be worn to keep her courtesy and undisturbed purity. ${ }^{24}$ According to the Jewish Law, a woman is very low before the man. ${ }^{25}$ In Jewish Law, a woman is like a thing and part of her husband treasure, which on it the husband has the full right to rule. ${ }^{26}$ The prophets said, God created a woman form the rib that always be protected; therefore courtesy has to be her main nature. ${ }^{27}$ In Jewish law and customs, there is no thought that women can prosecute all kinds of right equality with men. ${ }^{28}$

The approaching above, intended to help the researchers in analyzing issues which is circulated among the Corinth's congregation. From that approach, the researchers' temporary assumption stated that Christian women at Corinth didn't do tradition (custom) and culture which occured in that city. The women activity in the early church and man - woman equality in the Lord (1 Cor. 11:5, 11, 13), seem to be quite serious problem, considering church plurality which exists in the church of Corinth.

The researchers found out that the role of women in the church actually is not a new thing. Old Testament, recorded a "female judge," whose name was Deborah (Judg 4:4). Beside that, the New Testament also recorded several roles of women who prophesied (Acts 21:9). And then, Jesus in his ministry in the earth was also followed and served by women (Matt. 27:5). Several scriptures, show that it should be not a problem for women involve actively in church. But, a serious question is why this matter becoming a problem in church of Corinth? What actually was done by women believers in the city of Corinth? What were the objections appreared in the church and unbelievers in Corinth about women? This scripture indeed was a contextual problem in Eastern world. However, these contextual issues is contained Christian basic principle which is relevant for Christian in these days. This scripture is packaged in Paul's adorable language style. The ways of his conflict solutions indeed are unbeatable.

\section{Syntactical Analysis}

Syntaxis is one of the grammar branch that discuss the structures of sentence, clause, and
${ }^{24}$ Ibid., 178.
${ }^{25}$ Ibid., 178.
${ }^{26}$ Ibid., 178
${ }^{27}$ Ibid., 178
${ }^{28}$ Ibid., 179 
phrase. ${ }^{29}$ Syukur Ibrahim and friends explain syntaxis is part of linguistics that talks about the ins and outs of sentence, clause, and phrase. ${ }^{30}$ The construction of syntactical analysis intended to study the text so that the true meaning from that text is found. Kaiser, Jr. wrote:

We have seen, then, that at the heart of exegesis there should be a detailed syntactical analysis which involves identification of (1) the theme proposition; (2) the relationship (coordinate or subordinate) of all other sentences, clauses, and phrases in the paragraph to that theme proposition; and (3) the connection of the paragraph with other paragraphs. ${ }^{31}$

Kaiser, Jr. writing above explains that syntactical analysis comprises: (1) proposition theme, (2) relation (coordination or subordination) of all other sentencesm clauses, phrases in the paragraph for proposition theme; (3) also the relation between one paragraph to another paragraphs. Syntactical analysis covers identification of proposition theme, the relation between sentences and proposition theme, the relation between clauses and proposition theme, the relation between phrases and proposition theme.

\section{a. Proposition Theme}

Proposition theme is the core of every paragraph of the scripture which will be analyzed. ${ }^{32}$ It means that core of every verse is the theme or sentence topic/proposition. Proposition theme from 1 Corinthians 11:2-16 is about women leadership.

\section{b. The Relation of Phrases and Proposition Theme}

Phrase is grammatical unit in the form of a combination of non predicative word or one grammatical arrangement consisting of two words or more. ${ }^{33}$ Phrases which exist in 1 Corinthians 11:2-6 are as follows:

First phrase, "praise you" (v.2). This phrase

${ }^{29}$ Paitoon M. Chalyanara et all., Singapore International Journal of Language and Literature (Singapore: Singapore International Press, 2012), 158.

${ }^{30}$ Syukur Ibrahim, dkk., Bahan Ajar Sintaksis Bahasa Indonesia (Malang: Departemen Pendidikan Nasional Universitas Negeri Malang, t. t.), 1.

${ }^{31}$ Walter C. Kaiser, Jr., Toward An Exegetical Theology: Biblical Exegesis For Preaching And Teaching (Michigan: Baker Book House, 1993), 104.

\footnotetext{
${ }^{32}$ Ibid., 100.

${ }^{33}$ Zaenal Arifin dan Junaiyah, Sintaksis (Jakarta:
} Grasindo, t. t.), 4. explains that Paul gave praise because of reminding him to stay firmly keeping the ordinances. Therefore, the relation of first phrase with propositioan theme is a leader should stay firmly keeping the ordinances of Christ through Paul.

Second phrase, "the head of every man" (v.3). This phrase explains that the head of man is Christ. Therefore, the relation of second phrase with proposition theme is both man and woman have one head, that is Christ.

Third phrase, "every woman" (v.5). This phrase explains that at the age of Paul, every woman hooded her head to show courtesy and submission attitude towards her husband. Therefore, relation of third phrase and proposition theme is in women leadership, every woman has to show courtesy and submit to her husband, even though she has incumbency in leadership.

\section{c. The Relation of Clauses and Propositioan Theme}

Clause is grammatical unit in the form of words combination consisting at least one subject and one predicate. $^{34}$

First clause, "Now I praise you" (v.2). This clause explains that Paul gave praise because the ordinances he delivered still kept firmly.

Second clause, "The head of every man is Christ" (v.3). This clause explains that the highest authority which is owned by every man is Christ.

Third clause, "Every woman that prayed" (v.5). This clause explains than every woman who prays to God has to be in courtesy and submission.

Fourth clause, "ought the woman to have power on her head" (v.10). This clause shows that woman has authority on her head, that is her husband.

Fifth clause, "so is the man also by the woman" (v.12) This clause explains that man was born from woman. Even though a woman comes from a man, there is no male without a woman who giving birth.

\section{d. The Relation Of Sentences And Proposition Theme}

First sentence, "Now I praise you, brethren, that ye remember me in all things, and keep the ordinances, as I delivered them to you" (v.2). This sentence explains that Paul gave praise, because the ordinances he delivered was kept firmly.

Second sentence, "But I would have you know, that the head of every man is Christ; and the

\footnotetext{
${ }^{34}$ Ibid., 34.
} 
head of the woman is the man; and the head of Christ is God" (v.3). This sentence explains that both man and woman have the highest authority, that is Christ.

Third sentence, "But every woman that prayeth or prophesieth with her head uncovered dishonoureth her head: for tha is even all one as if she were shaven" (v.5). This sentence explains that every woman has to have courtesy and submission when she prayed to God.

Fourth sentence, "For this cause ought the woman to have power on her head because of the angels" (v.10). This sentence explains that every woman has to have the sign of authority on her head.

Fifth sentence, "For as the woman is of the man, even so is the man also by the woman; but all things of god" (v.12). This sentence explains that man and woman are the same in God's eyes.

\section{Verbal Analysis}

Virkler explains "“Lexical-syntactical analysis is the study of the meaning of individual words (lexicology) and the way those words are combined (syntax), in order to determine more accurately the author's intended meaning. "35 Verbal analysis is analysis which explains about the meaning of the words individually (lexicology) and the way those words combined (syntax), so that the true meaning can be obtained as intended by the book's writer. The researchers will do verbal analyzing which cover: lexical, grammatical, and historical, and of course the terms that will be studied has represent the features that summarize women leadership theme according to 1 Corinthians 11:2-16.

Those terms will be analyzed lexically, grammatically, and historically. Those terms are: remember (v.2), ordinances (v.2), know (v.3), head (v.3), dishonoureth (v.4), image (v.7), glory (v.7), created (v.9), power (v.10), angels (v.10), in the Lord (v.11), nature (v.14).

\section{a. Lexical}

The term of lexical means relating to dictionaries. ${ }^{36}$ Lexical analysis in this part will discuss the terms:

\section{1) The term 'remember' (v.2)}

\footnotetext{
${ }^{35}$ Virkler, Hermeneutics: Principles and Processes of Biblical Interpretation, 94.

${ }^{36}$ John M. Echols dan Hasan Shadily, "Leksikal," dalam Kamus Inggris Indonesia (Jakarta: Gramedia, 2000), 356.
}

The term 'remember' comes from the original word, the Greek New Testament $\boldsymbol{\mu} \varepsilon \boldsymbol{\mu} \boldsymbol{\eta} \boldsymbol{\boldsymbol { \sigma } \boldsymbol { \theta } \boldsymbol { \varepsilon }}$

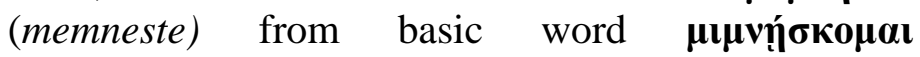
(mimesnkomai) which means remind oneself, recall to mind, remember, remember in the sense think of, be concerned about, be mentioned or be called to remembrance. ${ }^{37}$ Therefore, the term "remember" from its original word means to think of.

\section{2) The term 'ordinances' (v.2)}

The term "ordinances" comes from the original word, the Greek New Testament $\boldsymbol{\pi} \boldsymbol{\alpha} \boldsymbol{\rho} \boldsymbol{\alpha} \boldsymbol{\delta} \boldsymbol{\delta} \boldsymbol{\sigma} \boldsymbol{\varepsilon} \mathbf{\iota} \boldsymbol{\varsigma}$ (paradoseis) from basic word $\boldsymbol{\pi} \boldsymbol{\alpha} \boldsymbol{\rho} \boldsymbol{\alpha} \boldsymbol{\delta} \boldsymbol{\sigma o \sigma} \boldsymbol{\varsigma}$ (paradosis), which means tradition. ${ }^{38}$ Therefore, the term 'ordinances' from its original word, lexically means tradition.

\section{3) The term 'know' (v.3)}

The term 'know' comes from the original word, the Greek New Testament \&ỉośvol (eidenai) from basic word oĩ $\delta \boldsymbol{\alpha}$ (oida), which means know (about), you know or know! be (intimately) acquainted with, stand in a close relation to, know or understand how, can, be able, understand, recognize, come to know, remember, respect or take an interest in. ${ }^{39}$ Therefore, the term 'know' from its original word lexically means understanding.

\section{4) The term 'head' (v.3)}

The term 'head' comes form the original

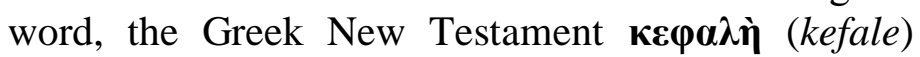

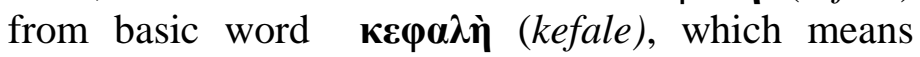
head, head denoting one of superior rank, head as extremity, end cornerstone, capital or frontier city. ${ }^{40}$ Therefore, the term 'head' from its original word lexically shows superior rank, superior/boss.

\section{5) The term 'dishonoureth' (v.4)}

The term 'dishonoureth' comes from the original word, the Greek New Testament

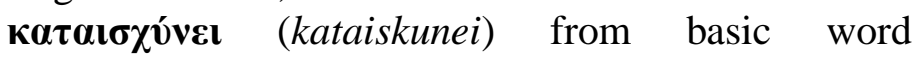

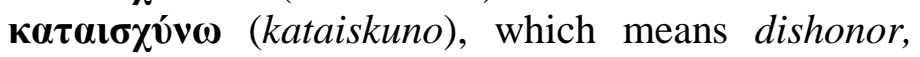
disfigure, be put to shame, be humiliated, humiliate, disappoint. ${ }^{41}$ Therefore, the term 'dishonoureth' from its basic word means disgrace/dishonor, a shame, and be humiliated.

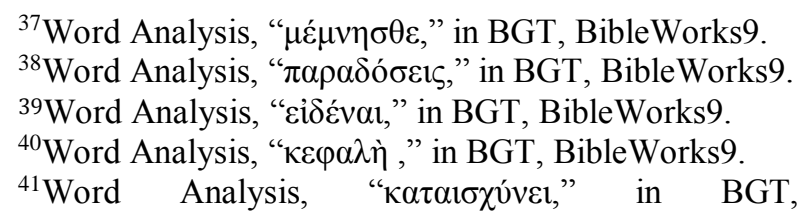


6) The term 'image' (v.7)

The term 'image' comes from the original word, the Greek New Testament \&ikòv (eikon)

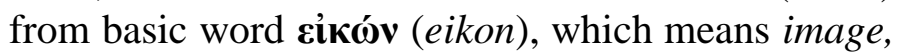
likeness form, appearance. ${ }^{42}$ Therefore, the term 'image' lexically means image, likeness.

7) The term 'glory' (v.7)

The term 'glory' comes from the original word, the Greek New Testament $\boldsymbol{\delta} \boldsymbol{o} \boldsymbol{\xi} \boldsymbol{\alpha}$ (doksa) from basic word $\boldsymbol{\delta} \boldsymbol{o} \xi \boldsymbol{\alpha}$ (doksa), which means brightness, radiance splendor, majesty as ascribed to God and heavenly beings, with connotation of power, magnificence, splendor, fame, renown, honor, prestige, praise as enhancement of reputation, glorious angelic beings, majesties, illustrious persons. ${ }^{43}$ Therefore, the term 'glory' lexically means majesty as ascribed to God and heavenly beings, with connotation of power, magnificence, splendor, fame, renown, honor, prestige.

8) The term 'created' (v.9)

The term 'created' comes from the original

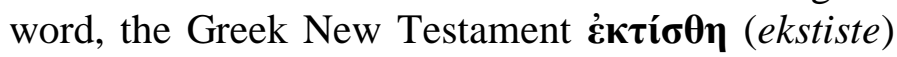
from basic word $\boldsymbol{\kappa} \tau^{\prime} \zeta \boldsymbol{\omega}(k t i z o)$, which means create $^{44}$ Therefore, the term 'created' lexically means made, realized.

\section{0) The term 'power' (v.10)}

The term 'power' comes from the original

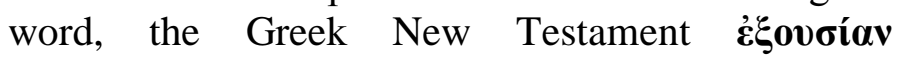

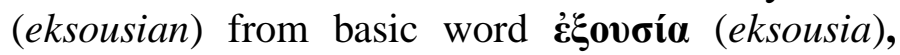
which means power, authority, absolute power, power or authority exercised by rulers, ruling power. $^{45}$ Therefore, the term 'power' lexically means power, authority.

\section{0) The term 'angels' (v.10)}

The term 'angels' comes from the original

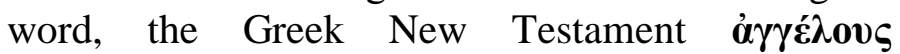

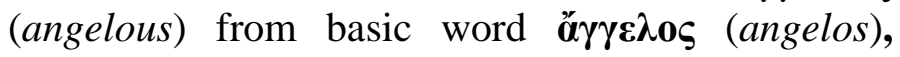
which means envoy, angel, a supernatural being who acts as messenger, guardian, mediator, and generally as the servant of God. ${ }^{46}$ Therefore, the term 'angels' lexically messengers, guardian.

11) The term 'in the Lord' (v.11)

\footnotetext{
${ }^{42}$ Word Analysis, "cikஸ̀v," in BGT, BibleWorks9.

${ }^{43}$ Word Analysis, " $\delta$ ó $\xi \alpha$," in BGT, BibleWorks9.

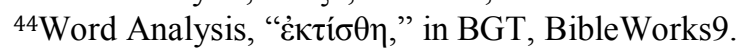

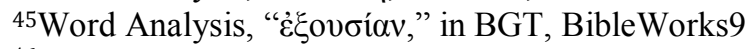

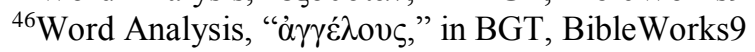

The term 'in the Lord' comes from the original words, the Greek New Testament $\dot{\boldsymbol{\varepsilon}} \mathbf{v}(e n)$ and

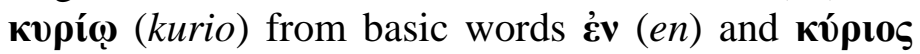
(kurios), which means in, in the presence of, dan Lord. ${ }^{47}$ Therefore, the term 'in the Lord' lexically means in the Lord. In His presence.

12) The term 'nature' (v.14)

The term 'nature' comes from the original word, the Greek New Testament pv́бıৎ (fusis) from basic word pv́бıs (fusis), which means nature, natural endowment or condition, natural characteristics or disposition, nature as the regular natural order. ${ }^{48}$ Therefore, the term 'nature' lexically means natural order, natural characteristics or disposition.

\section{b. Grammatical}

Grammatical analysis is analysis related with grammar. Grammatical analysis in this part will discuss the terms:

\section{1) The term 'remember' (v.2)}

The term 'remember' $\boldsymbol{\mu \varepsilon} \boldsymbol{\mu} \boldsymbol{\nu} \boldsymbol{\eta} \boldsymbol{\sigma} \boldsymbol{\varepsilon}$ (memneste) is verb indicative perfect passive 2nd person plural form. Verb is action word. Indicative perfect in Greek called perfect is really a present perfect. The perfect presents the action of the verb in a completed state or condition. ${ }^{49}$ Passive shows that Paul is the one who received this action. $2^{\text {nd }}$ plural means the second plural person here showing that church of Corinth thought about Paul. Therefore, grammatically the term 'remember' $\boldsymbol{\mu \varepsilon ́} \mu v \eta \boldsymbol{\sigma \theta \varepsilon}$ (memneste) means the church of Corinth thought about Paul. Eventhough the apostle wasn't with them, they kept thinking of him.

\section{2) The term 'ordinances' (v.2)}

The term 'ordinances' $\boldsymbol{\pi \alpha \rho \alpha \delta} \boldsymbol{\alpha} \boldsymbol{\sigma} \boldsymbol{\varepsilon} \mathbf{s}$ (paradoseis) is noun accusative feminine plural common form. Noun describes name,place,thing or idea. Accusative is as an object that have border function which stating the end or border of direct object action, in this case points to whom? what $?^{50}$ Feminine plural common is common plural form. Therefore, grammatically the term 'ordinances'

BibleWorks9.

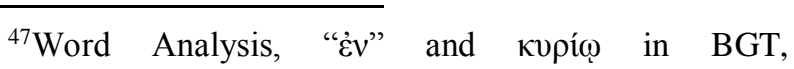

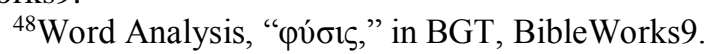

${ }^{49}$ William Hersey Davis, Beginner's Grammar of the Greek New Testament (Kentucky: Harper \& Brothers Publishers, 1923), 152.

${ }^{50}$ Ibid., 6. 
$\boldsymbol{\pi \alpha \rho \alpha \delta o ́ \sigma \varepsilon ı \varsigma ~ ( p a r a d o s e i s ) ~ m e a n s ~ a ~ t r a d i t i o n ~ w h i c h ~}$ continually doie by the church of Corinth. In this case surely Christian tradition given by Paul to the church of Corinth.

\section{3) The term 'know' (v.3)}

The term 'know' $\boldsymbol{\varepsilon} \mathbf{i} \boldsymbol{\delta} \boldsymbol{\varepsilon} \mathbf{v a l}$ (eidenai) is verb infinitive perfect active form. Verb shows action. Infinitive is an indeclinable verbal noun. As such it participates in some of the features of the verb and some of the noun. Like a verb, the infinitive has tense and voice, but not person or mood. It can take an object and be modified by adverbs. ${ }^{51}$ Perfect shows a finished work. Active shows the person does this action. Therefore, grammatically the term ' $\boldsymbol{\varepsilon} \mathbf{i} \delta \boldsymbol{\varepsilon} v \boldsymbol{\alpha}$ (eidenai)' means Paul desired the churh of Corinth knew what is in Christian faith.

\section{4) The term 'head' (v.3)}

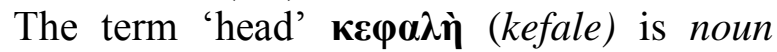
nominative feminine singular common form. Noun describes name, place, thing, and idea. Nominative describes subject, the doer. Feminine singular common is common singular form. Therefore,

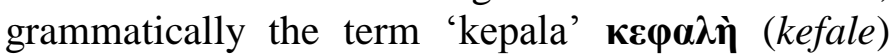
means God is the head of Christ, every man and woman.

\section{5) The term 'dishonoureth' (v.4)}

The term 'dishonoureth' which comes from

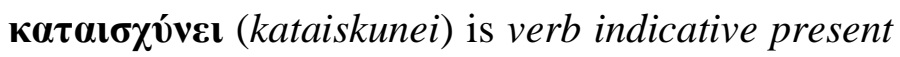
active 3rd person singular form. Verb shows action. Indicative present is a modus which is continually done, a job or condition which has to be done, the facts which are truly done. ${ }^{52}$ Active shows the person does this action. $3^{\text {rd }}$ person singular means he or she who is believer. Therefore, grammatically the

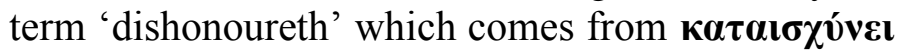
(kataiskunei) means a believer (man) dishonors his head if he is under the woman authority.

6) The term 'image' (v.7)

The term 'image' घikஸेv (eikon) is noun nominative feminine singular common form. Noun describes name, place, thing, and idea. Nominative describes subject, the doer. Feminine singular common is common singular form. Therefore, the term man's 'image' घik $\boldsymbol{\omega} \mathbf{v}$ (eikon) is an image of

\footnotetext{
${ }^{51}$ Daniel B. Wallace, Greek Grammar Beyond the Basics (Michigan: Zondervan Publishing House, 1996), 588.

${ }^{52}$ Davis, Beginner's Grammar of the Greek New Testament, 152.
}

God.

7) The term 'glory' (v.7)

The term 'glory' $\boldsymbol{\delta} \boldsymbol{o} \xi \boldsymbol{\alpha}$ (doksa) is noun nominative feminine singular common form. Noun describes name, place, thing, and idea. Nominative describes subject, the doer. Feminine singular common is common singular form. Therefore, the term 'glory' $\boldsymbol{\delta} \boldsymbol{o}_{\boldsymbol{~} \boldsymbol{\alpha}}$ (doksa) shows the man radiates God's glory.

8) The term 'created' (v.9)

The term 'created' $\mathbf{\varepsilon} \kappa \boldsymbol{\tau} \boldsymbol{\sigma} \boldsymbol{\sigma} \boldsymbol{\theta} \boldsymbol{\eta}$ (ekstiste) is verb indicative aorist passive 3rd person singular form. Verb shows action. Indicative is a modus of a statement that doesn't require conditions. Indicative aorist is a fact that truly happened, not a statement that require conditions, points to one time action, and doesn't continuously. ${ }^{53}$ Passive means the subject receives the action. $3^{\text {rd }}$ person singular means he or she who is believer. Therefore, the term 'created' $\dot{\varepsilon} \kappa \tau i ́ \boldsymbol{\sigma} \boldsymbol{\theta}$ (ekstiste) means a believer (woman) is created because of man.

\section{9) The term 'power' (v.10)}

The term 'power' $\mathbf{\varepsilon}$ govoíav (eksousian) is noun accusative feminine singular common form. Noun describes name, place, thing, and idea. Accusative shows as object that have border function which stating the end or border of the direct object action. Active shows the person does this action. Feminine singular common is common singular form. Therefore the term 'power' $\mathbf{\varepsilon} \xi \mathbf{o v \sigma} \boldsymbol{\sigma} \boldsymbol{\alpha} \boldsymbol{v}$ (eksousian) points to the woman has power.

10) The term 'angels' (v.10)

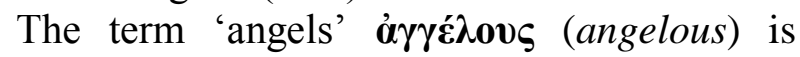
noun accusative masculine plural common form. Noun describes name, place, thing, and idea. Accusative shows as object that have border function which stating the end or border of the direct object action. Masculine plural common means common

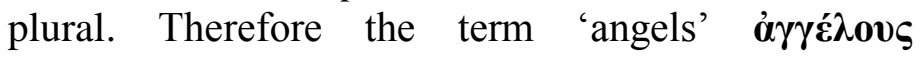
(angelous) points to angels.

\section{1) The term 'in the Lord (v.11)}

The term 'in the Lord' '̇े (en) and кvpí (kurio) are preposition dative and noun dative masculine singular common forms. Preposition dative in some respects, extended adverbs. ${ }^{54}$ Noun dative is

\footnotetext{
${ }^{53}$ Ibid., 152

${ }^{54}$ Wallace, Greek Grammar Beyond the Basics, 356.
} 
noun. Masculine singular common is common singular form. Therefore, the term 'in the Lord' $\dot{\boldsymbol{\varepsilon}} \mathbf{v}$ (en) and кvрí (kurio) points believers who have been redeemed by Christ.

\section{2) The term 'nature' (v.14)}

The term 'nature' pv́бıs (fusis) is noun nominative feminine singular common form. Noun describes name, place, thing, and idea. Nominative describes subject, the doer feminine singular common is common singular form. Therefore, the term 'nature' pv́otৎ (fusis) points to a rule in the life order.

\section{c. Historical}

Historical analysis explains about the history of the word usage based on the Bible text. Historical analysis which will discuss by the writers covers the term:

1) The term 'remember' (v.2)

The term 'remember' in the Greek New Testament is $\boldsymbol{\mu} \boldsymbol{\mu \nu} \mathbf{v} \boldsymbol{\sigma} \boldsymbol{\alpha} \boldsymbol{\mu} \boldsymbol{\alpha}$ (mimneskomai). Historically, Bromiley explains in Theological Dictionary of the New Testament, used in Septuaginta (LXX) and NT. In the LXX, this words for when God remembers people in grace and mercy, this is a creative event. ${ }^{55}$ While in the NT, "to remember" is not just a mental act. A word or action serves to kindle the memory. Recollection may strike or be continually present. ${ }^{56}$ Therefore, we can conclude that the church of Corinth always remember and think about Paul in all things (v.2). So, here we can see the church of Corinth was truly impressed by the person, the apostle, that they always remember and think about him. Surely this thing can be happened only because of the great love towards their apostle.

\section{2) The term 'ordinances' (v.2)}

The term 'ordinances' in the Greek NT is $\boldsymbol{\pi} \boldsymbol{\alpha} \boldsymbol{\rho} \boldsymbol{\alpha} \boldsymbol{\delta} \boldsymbol{\alpha} \boldsymbol{\prime} \iota \varsigma$ (paradosis. Historically, Bromiley explains in the NT, "what is transmitted" rather than "transmission." 57 This term also related with Christian teaching is also tradition. ${ }^{58}$ Therefore, what intended as ordinances in this scripture is Christian faith or Christian teaching, which have

${ }^{55}$ Gerhard Kittle and Gerhard Friedrich, trans. Geoffrey W. Bromiley, Theological Dictionary of the New Testament, (Grand Rapids, Michigan: William B. Eerdmans Publishing Company, 1992), 495.

${ }^{56}$ Ibid., 495.

${ }^{57}$ Ibid., 168.

${ }^{58}$ Ibid., 168. been received by Paul and then received by the church of Corinth that have to be tradition they kept and done.

\section{3) The term 'know' (v.3)}

The term 'know' in the Greek NT is oi $\boldsymbol{\delta} \boldsymbol{\alpha}$ (oida). Historically, Bromiley explains this term means "to know" and is more or less synonymous with ginôskō, is often used in the NT in a general way, e.g., to know a person, to be able to understand, to apprehend, and to recognize. ${ }^{59}$ Therefore, that term means understanding the teaching/ordinaces will be delivered by Paul.

\section{4) The term 'head' (v.3)}

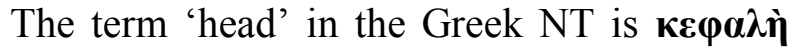
(kefale). Bromiley explains this term in LXX as "head" and "point" or "top, and in Judaism "head of the priesthood" or "of the world's idolaters" and Adam is called the "head of all created things," in hellenistic and gnostic "a special sense in connection with the aeon and the primal man." While in the NT the term often means the human or animal "head" with no theological significance, and especially in the passion narrative, the head of the risen Lord. In the Letter to Corinthians, the term 'head' means:

Christ is the head of man, man of woman, and God of Christ. Hence man should not cover his head, since he is the image and glory of God, but woman should do so, since she is the glory of man. The distinction between man and woman is seen here to have an ontological ground, for while man is God's reflection directly, woman is so only indirectly, having her life from man and for man. It is by reason of this basic distinction that charismatically gifted women should cover the kephalé when praying or prophesying. Not to do so is to offend against the head in the twofold sense; the long hair that phýsis gives women for a covering is an indication of this .60

Therefore this term means leader, that is the higher position, even the highest (God).

5) The term 'dishonoureth' (v.4)

The term 'dishonoureth' in the Greek NT is

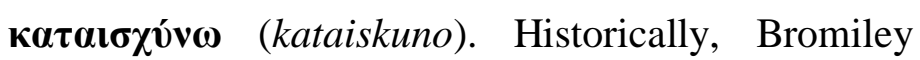
explains the use of this term in The Linguistic Usage in the LXX as "to shame," "put to shame" (God mostly as subject), "be shamed or ashamed" (personally rather than publicly). While in the NT, 
"to shame", "to bring to shame", "to be ashamed", almost "disillusioned", "what is disgraceful" (1 Cor. 11:6). ${ }^{61}$ Therefore the term 'dishonoureth' means to shame, be humiliated (disgraced) if the man is under the authority of woman or a woman leads the man.

6) The term 'image' (v.7)

The term 'image' in the Greek NT is عikóv (eikon). Historically, Bromiley explains this term in Greek as "to be like, "similar", "to appear," "image" (a). as an artistic representation, (b). as a mental image, and (c). as a likeness or manifestation. ${ }^{62}$ While in the NT, this term means :

Paul can also apply Gen. 1:27 to the male so as to bring out certain practical consequences for daily conduct. A little later, however, on the basis of Gen. 5:3, he contrasts our present bearing of the image of the earthly man with our future bearing of the image of the heavenly man. The idea here is that our being as the eikón of God is restored by union with Christ as eikón. This comes out plainly in Rom. 8:29, where our being conformed to Christ is given its distinctive emphasis by the fact that this means participation in his divine likeness. Those who are in Christ's image are in God's image in the true and original sense of Gen. 1:27. This likeness is the goal. ${ }^{63}$

Therefore, this term means the image of God, which has the likeness of God's characteristics. In this case, it means 'power'. So, every man has power over a woman.

6) The term 'glory' (v.7)

The term 'glory' in the Greek NT is $\boldsymbol{\delta} \boldsymbol{o} \xi \boldsymbol{\alpha}$ (doksa). Historically, Bromiley explains from Greek, Josephus dan Philo, LXX and Hellenistic Apocrypha means "opinion or tenet", "honor or glory", "splendor", and "divine radiance". While in the NT, shows "reputation" or "power," "acknowledging" or "extolling what is already a reality." 64 Therefore every man has power which is God's representation.

7) The term 'created' (v.9)

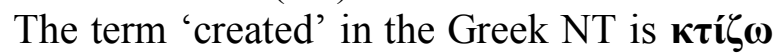
(ktizo). Historically, Bromiley explains in the NT, this term means applies only to God's creation. ${ }^{65}$

\footnotetext{
${ }^{61}$ Ibid., 37.

${ }^{62}$ Ibid., 37.

63Ibid., 204.

64Ibid., 180.

${ }^{65}$ Ibid., 180.
}

Therefore, this term means woman is created by God because of the man. It means, a man cann't live alone.

8) The term 'power' (v.10)

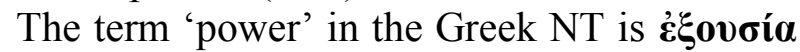
(eksousia). Historically, Bromiley explains in Greek, Jewish, LXX, Philo, rabbinic means "ability", "right", "authority", "permission." While in the NT, this term means:

In context the verse is part of the discussion of veiling. The verb opheillei implies obligation rather than compulsion and thus suggests a moral duty. It seems, then, that the veil is a sign of subordination and the angels are guardian angels or watchers over the natural order, exousia is thus used materially for the veil in a bold image suggesting male dominion. Alternatively it might be due to a confusion or intentional equation of the Aramaic stems for "to conceal" on the one hand and "to rule" on the other. ${ }^{66}$

Therefore, this term means power. The cover for a woman is a power/authority, means she is under man's power.

\section{0) The term 'angels' (v.10)}

The term 'angels' in the Greek NT is ớ $\gamma \gamma \varepsilon \boldsymbol{\lambda} \mathbf{0} \boldsymbol{\varsigma}$ (angelos). Historically, Bromiley explains this term in Greek and Hellenistic Word which means "messenger." In the OT, it means "angel of the Lord." While in the NT, this term means "human messenger." ${ }^{97}$ Therefore, this term means messenger who brings the message from God.

\section{1) The term 'in the Lord' (v.11)}

The term 'in the Lord' according to the Greek NT language is the combination $\boldsymbol{\varepsilon} \mathbf{v}(e n)$ and кv́pıs (kurios). Historically, Bromiley explains in NT shows the "membership in Christ and his church."68 Therefore, this term means fellowship or relation between Christ and His people. Christ as the head and the believers as the Body of Christ's member, has been united in His blood as the eternal fellowship.

12) The term 'nature' (v.14)

The term 'nature' in the Greek NT is pv́oıs (fusis). Historically, Bromiley explains in Greek Literature (Homer and Pindar - pre-Socratic Philosophy) means "form" or "nature", "budding", "growth" or "development", "first in relation to

\footnotetext{
66Ibid., 240.

${ }^{67}$ Ibid., 13.

68Ibid., 233.
} 
plants, then animals and people, "external form", "physical descent", "natural." In Jewish Literature (Philo, josephus) means "nature", "species", "aptitude", "universal nature" (contrasted with both law and reason in 4 Maccabees), and "physical nature". While in the NT, especially in the Corinthians, this term means personified as a teacher; it reminds us of what is seemly. ${ }^{69}$ Therefore, Paul wants to emphasize what is appropriate in Christian life.

\section{Theological Analysis}

Theological analysis is analysis related with systematic theology. Women leadership according to 1 Corinthians 11:2-16, if noticed from two sides of systematic theology, covers God's Doctrine (Theology of God), Christology (Theology of Christ), Anthropology (Human Theology), Ecclesiology (Church Theology).

Doctrinally, God can be explained. God is the highest authority and all things come from Him. Christologically, can be explained that Jesus Christ is the head of every man and in Him there is no separation between man and woman. It means both are interdependent and depend on God, Christ who reconciled humans and God. Anthropologically, can be explained that man reflects the image and the glory of God, man is also the head of woman, so the woman who is created because of man have to submit to him. Ecclesiologically, can be explained that either man or woman can pray and prophesy, but they need to understand the hierarchy that predetermined by God, that man is the head of woman, and Christ is the head of man. It means, Christ is the head of the church.

Therefore, theologically, God is the owner of the highest authority, all have to obey Him. Christ doesn't cancel the ordo set previously by God, but through His blood $\mathrm{He}$ has made them live interdependently, especially to Him whom redeemed the believers' sins. Therefore, in the Church, Christ is the head and the believers are the part of the body of Christ. According to the ordo, the man is the head of each woman, so clearly we can conclude that woman leadership is very contradictory with what has been predetermined. However, in some cases the women leadership can be happened if no man is capable or worthy to execute the leadership and that matter is permitted by God.

\section{Conclusion}

${ }^{69}$ Ibid., 1286.
The woman leadership is the leadership which is not in accordance with the ordo determined by God. The man is the head who has power and authority over woman. However, it does not mean the man can treat the woman as a slave. Christ teaches dependency, there is no man without woman, there is no woman without man. It this matter Paul will speak about love. As God has loved us, so do we love each other in Christ. There is no obedience without love, otherwise there is no love without obedience. The woman has to obey the man, likewise the man loves the woman.

From the explanation above, it does not mean woman can not be active in a church. A woman can do many things, likewise a man. One thing to be considered is self awareness of what has been predetermined by God. It needs humility and self submission to God to do this thing. A man can not forget his responsibility as a head, as well as a woman as a helper. What becomes the problem is not about who is the highest or has more influence, but the function of each creation. The woman leadership is a special case permitted by God. However, this matter mostly happened because of the lack of responsibility and awareness of man toward God's precept.

Through 1 Corinthians 11:2-16, Paul wants explains the reader that God has predetermined the head of every man is Christ and the head of woman is man. This determination applies forever and nothing can change or add God's precept. Through contextual analysis be discovered Paul wants emphasize either man or woman has self-awareness towards God's predetermined precept. A man is a head, has power and responsibility as leader. While a woman has the sign of power (there is authority over her), therefore woman always obeys to the authority over her, the man. In this matter, clearly Paul teaches Christian ordinances which has become familial tradition.

In 1 Corinthians 11:2-16 Paul does not only lead each of his readers to what predetermined by God, but also reminds each person who has been redeemed by Christ that in the Lord, man and woman need each other, interdependent, and intertwined. In this matter, Paul wants to emphasize about love. It does not mean a man as leader treats a woman arbitrarily as he wants. Obedience and love are not separate, both happened coincidently. A man has to guide and lead a woman with love. Not only his desires are satisfied, but Paul wants the man loves someone under him, a woman. Likewise, a woman has to do the instruction and her responsibility based on love. God's love overflows in His children, which allows either man or woman doing God's will 
precisely.

Paul also emphasize what he has taught are not contradictory with nature. So, what is biblical woman leadership? Through in-depth analysis as mentioned above, woman leadership which more influencing, directing, guiding others, including the man, surely is not in accordance with what predetermined by God. In this text clearly mentioned that a man is a leader, not a woman. The woman does her role as a man's helper. A woman has to obey the man and a man leads with love. This directs us to the functions which has been determined by God. Each creation has to exercise God's command and be full responsible over what have been trusted.

It's explained in several cases in the Bible there are woman's roles in leadership. But, that is a special condition which is not detached from God's permit. If we face this thing we will not immediately judge that's not biblical. Is there really no man in a certain group? Or maybe the man is not capable or worthy, so the woman leadership applied? If it happened, with full of humility and love, as a woman we have to support and help him to be a leader suitable with God's will. This is what Paul intended in this text, not to limit the woman in church matter, but to remind the responsibility and responsibility of man and woman before God.

\section{References}

[1] 100 Wanita Paling Berpengaruh di Indonesia - 31 Januari 2010, http://jenstea.wordpress.com/2010/01/31/10 -wanita-paling-berpengaruh-di-indonesia. Accessed: 28-10-2018 22:14

[2] 100 Wanita Paling Berpengaruh Sejagat Jum'at, 4 Januari 2013, http://life.viva.co.id/news/read/379416100wanita-paling-berpengaruh-sejagat.

Accessed: 28-10-2018 22:17

[3] Arifin, Zaenal dan Junaiyah. Sintaksis. Jakarta: Grasindo, t. t.

[4] Barclay, William. Pemahaman Alkitab Setiap Hari: Surat 1 \& 2 Korintus. Jakarta: Gunung Mulia, 2008.

[5] BibleWorks9, LLC. 3800 Colley Avenue \#6158 Norfolk, VA 23508

[6] Chalyanara, Paitoon M., et all. Singapore International Journal of Language and Literature. $\quad$ Singapore: Singapore International Press, 2012.

[7] Drane, John. Memahami Perjanjian Baru.
Jakarta: BPK Gunung Mulia, 1996.

[8] Echols, John M. dan Hasan Shadily. Kamus Inggris Indonesia. Jakarta: Gramedia, 2000.

[9] Hillyer, Norman. Tafsiran Alkitab Masa Kini. Volume 3. Translator Harun Hadiwijono. Jakarta: Yayasan Komunikasi Bina Kasih/OMF, 1986.

[10] http://lifestyle.bisnis.com/read/20180308/22 0/747784/survei-women-in-business-kinerjaperusahaan-naik-jika-perempuan-lebihbanyak Accessed: 2-10-2018 18:39

[11] http://webstersdictionary1828.com/Dictionar y/leader Accessed: 29-10-2018 21:12

[12] http://www.gurupendidikan.com/21-definisikepemimpinan-menurut-para-ahli/ Accessed: 29-10-2018 21:12 Accessed: 28-09-2018 19:02

[13] Ibrahim, Syukur; dkk. Bahan Ajar Sintaksis Bahasa Indonesia. Malang: Departemen Pendidikan Nasional Universitas Negeri Malang, t. t.

[14] Johnson, S. Lewis. The Wycliffe Bible Commentary: Tafsiran Alkitab Wycliffe. Volume 3. Editor Charles F. Pfeiffer. Translator Gandum Mas. Malang: Gandum Mas, 2007.

[15] Kaiser, Walter C. Jr. Toward An Exegetical Theology: Biblical Exegesis For Preaching And Teaching. Michigan: Baker Book House, 1993.

[16] Kristanto, Billy. Ajarlah Kami Bertumbuh. Surabaya: Momentum, 2011.

[17] Maxwell, John C. Developing The Leader Within You: Mengembangkan Kepemimpinan Di Dalam Diri Anda. Jakarta: Binarupa Aksara, 1995.

[18] Oxford Advanced Learner's. Oxford Advanced Learner's Dictionary of Current English. Oxford: Oxford University Press, 1974.

[19] Pena, Tim Prima. Kamus Besar Bahasa Indonesia. Jakarta: Gitamedia Press, t. t.

[20] Stamps, Donald C. Full Life Study Bible: Alkitab Penuntun Hidup Berkelimpahan. Translator Nugroho Hananiel. Editor Bertha Gaspersz. First Printing. Malang: Gandum Mas, 1994.

[21] Terry, Robert W. Kepemimpinan Autentik. Batam Center: Interaksara: 2002.

[22] Virkler, Henry A. Hermeneutics: Priciples and Process of Biblical Interpretation. Twelfth printing. Grand Rapids, Michigan: 
Baker Book House, 1993.

[23] Webster's New World. Webster's New World Compact Desk Dictionary And Style Guide. USA: Macmillan, 2002. 